\title{
Development of Macromedia Flash-Assisted Mathematics Learning Media with the Application of Problem Based Learning Models to Improve Computational Thinking Ability and Self-Efficacy of Class X High School Students
}

\author{
Yuli Astrinitha Lubis, Asmin, Bornok Sinaga \\ Mathematics Education Study Program, Medan State University, Indonesia
}

\begin{abstract}
This development research uses a 4-D design model by Thiagarajan, namely define, design, develop, and disseminate. However, in this study only at the development stage. The subjects of this study were 20 students in class X Mathematics and Natural Sciences at the Private MA Miftahul Falah Diski. The validity of the learning media developed in terms of the analysis of the results of the validity of the learning media by the validators with a total average value of 3.72 (category "Valid"). Meanwhile, the practicality of learning media is seen from the observation score of the implementation of learning in the second trial, which is 3.71 (category "Well Implemented"). The effectiveness of learning media in terms of four aspects, namely classical completeness, student active activity observation scores, student self-efficacy scores, and student responses. The classical completeness of students' computational thinking ability in the second trial was $87 \%$ (17 students). The average percentage of students' achievement in the ideal time of activity in the second trial for three meetings was $21.98 \%$, $20.2 \%, 21.7 \%, 26.5 \%, 10.9 \%$, and $1.9 \%$. The average score of the overall self-efficacy scale in the second trial for three meetings was 3.16 so it was included in the positive category. The average student response in the second trial was $91.6 \%$ (category "Interested"). Based on the normalized gain index, it was found that in the second trial there was an increase in the value with a score of 0.4 (the "medium" criterion). The average score of the overall self-efficacy scale in the second trial for three meetings was 3.16 so that it was included in the positive category. The average student response in the second trial was $91.6 \%$ (category "Interested").

Keywords: Macromedia Flash, Problem Based Learning, Computational Thinking Ability, Self-Efficacy, Development of Mathematics Learning Media, Three Variable Linear Equation System.

DOI: $10.7176 / \mathrm{JEP} / 12-34-03$
\end{abstract}

Publication date: December $31^{\text {st }} 2021$

\section{INTRODUCTION}

Education is a process that helps humans learn, so that the results of the process can be used in dealing with certain problems. Education is a conscious effort to prepare students through guidance, teaching, and training activities as their role in the future. Trianto $(2011: 1)$ reveals that: "Good education is education that is able to support future development, which means being able to develop the potential of students, so that those concerned are able to face and solve life problems they face. Education must touch the potential conscience and competence potential of students. The draft of the 2021 PISA framework which was released by the OECD, in November 2018 showed several interesting things to discuss, one of the main ones being the inclusion of computational thinking in the 2021 PISA assessment, this is different from the previous PISA. Even the Ministry of Education and Culture (Kemendikbud) in 2019 also launched two new competencies in the learning system in Indonesia. One of them is computational thinking competence.

Computational thinking is an abstract mental activity which includes reasoning processes such as abstraction, decomposition, pattern mapping, pattern recognition, and algorithmic thinking (Città et al., 2019). Based on the above opinion, it can be concluded that the ability to think computationally is the ability to think to solve a problem thoroughly, logically and regularly, this also means that the ability to think computationally can be categorized as a high-level thinking ability.

Based on the pre-research conducted in class X of the private MA Miftahul Falah Diski through giving a test on the material of a three-variable linear equation system, it shows that the stages of computational thinking carried out by students only reach the stage of decomposition and pattern recognition. Not only that, students also have not been able to use abstractions to the given mathematical problems. The students' algorithmic thinking skills have also not been seen because there are stages of problem solving that students do illogically and systematically. Therefore, it can be concluded that the students' computational thinking ability is still low. Students' low computational thinking ability can certainly be influenced by many factors. These factors can be grouped into two, namely internal factors and external factors. Internal factors include the preparation of students in the teaching and learning process. External factors are teaching materials, strategies, learning models, learning media and the state of the learning environment. Efforts that can be made to improve students' computational thinking skills and selfefficacy are the use of appropriate learning models, one of which is the Problem Based Learning (PBL) learning 
model. Problem-Based Learning (PBL) learning model is a learning model that can provide active learning conditions for students. PBL is a learning model that involves students to be able to solve a problem with the stages of the scientific method so that students can learn knowledge related to the problem and at the same time have the skills to solve problems. (Syamsidah et al: 2018).

However, in reality the use of learning media in schools is still not optimally used by teachers. This the authors know when looking at the learning tools compiled by the teacher have not included the learning media that will be used in learning activities clearly and in detail, especially in the three-dimensional space material. The learning media used are still very lacking so that teachers use the media minimally when teaching in schools.From the results of interviews with mathematics teachers at the Private MA Miftahul Falah Diski and observations during the mathematics learning process, it can be concluded that teachers do not yet have the skills to develop learning media by utilizing applications and other computer software. only macromedia flash

The mathematics teacher at the Private MA Miftahul Falah Diski stated that the reason for this was not only because teachers still found it difficult to use and utilize applications on computers, but also because the process of making media took a lot of time so teachers were reluctant to develop learning media. One alternative to grow students' computational thinking skills is to use mathematics learning media. There are many media that can be used, including macromedia flash program. The macromedia flash program is a dynamic and interactive program to support learning and solving math problems. With a variety of facilities, the macromedia flash program can be used as a learning medium. The use of macromedia flash in learning has been done by many researchers or other educators. For example, in Darma's research (2020) on the development of macromedia flash-based learning media containing Problem Posing on students' mathematical problem solving abilities, it shows that the mathematical problem solving abilities of students who learn to use these media are high. Naibaho (2014) in his research on the application of Problem Based Learning (PBL) using macromedia flash animation media to improve students' mathematical problem solving abilities, also shows evidence that students' problem solving abilities can increase after being taught by using macromedia flash assisted learning media.Based on the description above, the researchers are interested in developing learning media to improve students' computational thinking skills entitled: "Development of Macromedia Flash Assisted Learning Media with the Application of Problem Based Learning (PBL) Learning Models to Improve Computational Thinking Ability and Self-Efficacy of Class X Students SENIOR HIGH SCHOOL."

\section{LITERATURE REVIEW}

\section{Computational Thinking Ability}

Computational Thinking (Computational Thinking) is a method of solving problems by applying the techniques used by a computer software expert in writing programs. But computational thinking is not thinking like a computer, but thinking about computational, meaning that one is required to (1) formulate a problem in the form of a computational problem and (2) develop a good computational solution (in the form of an algorithm) or explain why a suitable solution is not found (Malik , 2018). According to Ian Horswill (in Santoso; 2020) computational thinking is finding a solution to a problem from the input given by means of an algorithm. Computational thinking includes two major steps, namely the process of logical thinking (reasoning) followed by decision making or problem solving (problem solving).

Ioannidou (in Santoso: 2020) summarizes computational thinking techniques including:

a. Decomposition: decomposition or the process of changing complex problems into simpler things.

b. Pattern recognition: Pattern recognition in problem solving is the main key to determining the right solution to a problem and to knowing how to solve a particular type of problem.

c. Abstraction: related to the identification of patterns, similarities and relationships, such as the process of recognizing patterns both in the data that is being used and in the process/strategy used.

d. Algorithm design: ways to get a solution through a clear definition of the steps taken.

\section{Self-Efficacy Student}

Self-efficacyconsists of the word "self" which can be interpreted as an element of personality structure and "efficacy" which means self-assessment, whether it can do good or bad actions, right or wrong, biased or unable to do something. Self-efficacy is synonymous with "self-confidence". Baron and Byrne (in Fitriani, 2011:110) define Self-efficacy as a person's evaluation of one's ability or competence to perform a task, to achieve a goal, or to overcome a problem. It can be said, Self-efficacy is related to the knowledge and experience of the students themselves. Someone who understands the concept being studied will increase self-efficacy, and vice versa.

Self-efficacyaffect the motivation of each individual, what efforts are made to foster a sense of confidence and the extent to which they can be confident in carrying out a task. It can be concluded that self-efficacy is an individual's belief in facing and solving problems he faces in various situations and being able to determine actions in completing certain tasks or problems, so that the individual is able to overcome obstacles and achieve the expected goals. 


\section{Macromedia Flash}

Macromedia Flashis software that is widely used by web professionals because of its amazing ability to display multimedia, combining elements of text, graphics, animation, sound and as well as interactivity for users of internet animation programs. Today Macromedia Flash has become a favorite of web designers as a means to create an attractive and interactive website.

Macromedia flash can be used to create an animation. Animation is "an arrangement of objects arranged in such a way as to produce a movement that is able to attract everyone to see it", in order to produce interesting animations that are in accordance with research objectives, macromedia flash learning media must be well designed (Astuti, 2006: 111). This program can display information in the form of writing, images, animations, so that students can be more interested in participating in mathematics lessons. Arsyad (2015: 36) says that: "interactive media is the choice of media based on the latest technology. One of the good and up-to-date interactive learning media is learning media using macromedia flash applications to make the learning display more attractive for students to learn."

\section{Learning model Problem Based Learning}

Problem Based Learning (PBL) is one of the learning models that can help students to improve the skills needed in the current era of globalization. Tan (in Rusman: 2012) says that; Problem Based Learning (Problem Based Learning) is an innovation in learning because students' thinking abilities are really optimized through a systematic group or team work process, so that students can empower, hone, test, and develop their thinking skills on an ongoing basis.

According to Ibrahim and Nur (in Rusman; 2012) suggest that the steps of Problem Based Learning are as follows: The first stage is the process of student orientation to the problem. At this stage the teacher explains the learning objectives, explains the logistics needed, motivates students to engage in problem solving activities, and poses problems. The second stage, organize students. At this stage the teacher divides students into groups, helps students define and organize learning tasks related to the problem. The third stage, guides individual and group investigations. At this stage the teacher encourages students to collect the information needed, carry out experiments and investigations to get explanations and problem solving. Fourth stage, develop and present results. At this stage the teacher assists students in planning and preparing reports, documentation, or models, and helps them share assignments with their friends. The fifth stage, analyze and evaluate the process and results of problem solving. At this stage the teacher helps students to reflect or evaluate the process and results of the investigations they are doing.

\section{METHOD}

This research was conducted at the Private MA Miftahul Falah Diski in the odd semester of the 2021/2022 academic year. The subjects in this study were students of class X-MIPA Private MA Miftahul Falah Diski. The object of this research is the learning media assisted by Macomedia Flash with the application of the Problem Based Learning learning model on the material of a three-variable linear equation system. This type of research is Research and Development using the 4-D Thiagarajan model.

\section{Data Collection}

The data collection instrument consisted of a validation sheet that was used to obtain data on the quality of learning devices based on the assessment of experts. Some of the validation sheets used include: validation sheets for learning media experts; validation sheet for Learning Implementation Plan (RPP); validation sheet for Student Worksheet (LKPD), students' computational thinking ability test, student self-efficacy questionnaire and student response questionnaire. The data obtained from the results of the computational thinking ability test were analyzed to determine the improvement. The data was obtained from the results of the pre-test and post-test of students' computational thinking ability. To calculate the increase in students' computational thinking ability, the n-gain value is determined first. In calculating n-gain, the formula is used (Lestari and Yudhanegara, 2015: 235):

Description:

$$
\text { Normalized gain }=\frac{S_{\text {post }}-S_{\text {pre }}}{S_{\text {max }}-S_{\text {pre }}}
$$

$\begin{array}{ll}N-\text { Gain } & =\text { normalized gain score } \\ S_{\text {post }} & =\text { final test score } \\ S_{\text {pre }} & =\text { preliminary test scores } \\ S_{\text {max }} & =\text { maximum score }\end{array}$


Table 1.

N-Gain Score Criteria

\begin{tabular}{c|c}
\hline Gain Score (g) & Criteria \\
\hline $\mathrm{g} 0.3 \leq$ & Low \\
\hline $0.3<\mathrm{g} 0.7 \leq$ & Currently \\
\hline $\mathrm{g}>0.7$ & Tall \\
\hline
\end{tabular}

Source: (Hake, 1999)

\section{RESULTS AND DISCUSSION \\ 1. Validity of Interactive Digital Book Learning Media}

Table 2.

Summary of the Validation Results of Macromedia Flash Assisted Learning Media and Validated Learning Instruments

\begin{tabular}{llc}
\hline \multicolumn{1}{c}{ Validated Instrument } & Score & Category \\
\hline Instructional Media & 3.72 & Valid \\
\hline PBL lesson plan (RPP) & 3.73 & Valid \\
\hline Student Worksheet (LKPD) & 3.82 & Valid \\
\hline Initial test of computational thinking skills & 3.84 & Valid \\
\hline Computational thinking ability final test & 3.75 & Valid \\
\hline Student Self Efficacy Questionnaire & 3.88 & Valid
\end{tabular}

\section{Practicality of Macromedia Flash Assisted Learning Media}

The practicality of developing macromedia flash-assisted learning media has met the practical criteria in terms of the results of the assessments of the experts (validators), all validators stated that the developed macromedia flashassisted learning media was feasible to use with a slight revision. Then, observing the implementation of learning using learning media assisted by macromedia flash in table 3 below:

Table 3.

Summary of Observation Results of Learning Implementation

\begin{tabular}{|c|c|c|c|c|c|c|c|c|}
\hline & \multicolumn{4}{|c|}{ Trial I } & \multicolumn{4}{|c|}{ Trial II } \\
\hline & $\mathrm{I}$ & II & III & IV & $\mathrm{I}$ & II & III & IV \\
\hline Score & 2.66 & 2.7 & 2.8 & 2.8 & 3.52 & 3.78 & 3.8 & 3.8 \\
\hline Average & \multicolumn{4}{|c|}{2.74} & \multicolumn{4}{|c|}{3.72} \\
\hline Category & \multicolumn{4}{|c|}{ Implemented Poorly } & \multicolumn{4}{|c|}{ Well done } \\
\hline
\end{tabular}

Based on the table, it can be seen that the learning implementation observation score did not meet the practicality criteria in the first trial, namely with an average score of 2.745 in the first trial (category "Implemented Poorly"). While in the second trial, an average score of 3.72 was obtained in the "Well Implemented" category.

\section{The Effectiveness of Macromedia Flash Assisted Learning Media}

\section{Student Computational Thinking Ability Test Achievement}

Based on the results of the test analysis in trials I and II, it was found that the students' computational thinking ability had met the classical completeness criteria. The description of the results of students' computational thinking abilities is shown in table 4 below:

Table 4.

Summary of Student Computing Thinking Ability Test Achievement

\begin{tabular}{cc}
\hline \multirow{2}{*}{ Testing } & Achievement on \\
\cline { 2 - 2 } & Reasoning Ability \\
\hline I & $55.2 \%$ \\
\hline II & $87 \%$
\end{tabular}

The achievement of the final test of students' reasoning ability and understanding of mathematical concepts in the first trial was 55.2\% with 11 students declared complete. So, it can be concluded that in the first trial the application of learning media assisted by macromedia flash developed did not meet the criteria for achieving classical completeness $(>80 \%)$. However, in the second trial, the achievement of the final test of students' computational thinking skills had met the specified criteria, which was $87 \%$ with 17 students being declared complete. Thus, it can be said that the learning media assisted by macromedia flash has met the effectiveness criteria in the aspect of achieving students' reasoning abilities and understanding of mathematical concepts.

\section{Student Activities}

Based on the results of the first trial, it can be concluded that all student activities meet the ideal percentage of 
time set. The summary can be seen in table 5 below:

Table 5.

Summary of Ideal Percentage of Student Activities in Trials I and II

\begin{tabular}{|c|c|c|c|c|}
\hline Observation Aspect & $\begin{array}{c}\text { Trial } \\
\text { Average I }\end{array}$ & $\begin{array}{l}\text { Trial Average } \\
\text { II }\end{array}$ & $\begin{array}{c}\text { Time } \\
\text { Ideal } \\
(\%)\end{array}$ & Tolerance \\
\hline $\begin{array}{l}\text { Observing the presentation of material with learning } \\
\text { media }\end{array}$ & 21.8 & 21.8 & 20 & $\begin{array}{c}15 \% \text { P } 25 \% \leq \\
\leq\end{array}$ \\
\hline Asking problems in learning media or LKPD & 18.4 & 19.2 & 30 & $\begin{array}{c}25 \% \text { P } 35 \% \leq \\
\leq\end{array}$ \\
\hline Looking for information to add insight into the material & 20.9 & 21.5 & 30 & $\begin{array}{c}25 \% \text { P } 35 \% \leq \\
\leq\end{array}$ \\
\hline Reasoning/associating learning and presented LKDP & 26.0 & 26.0 & 10 & $5 \%$ P $15 \% \leq \leq$ \\
\hline $\begin{array}{l}\text { Communicating about the learning process, results and } \\
\text { conclusions }\end{array}$ & 10.7 & 9.8 & 10 & $5 \%$ P $15 \% \leq \leq$ \\
\hline Doing activities that are not relevant to learning & 3.0 & 1.8 & 0 & $0 \%$ P $15 \% \leq \leq$ \\
\hline
\end{tabular}

\section{Student Self Efficacy}

Based on the analysis of the results of student self-efficacy observations, it was found that in the first and second trials, students' self-efficacy in learning mathematics using macromedia flash-assisted learning media on the threevariable linear equation system material was in the positive category. More clearly, the data is shown in Table 6 below:

Table 6.

Summary of Student Self-Efficacy Questionnaire Analysis Results

\begin{tabular}{ccccc}
\hline Dimension & \multicolumn{2}{c}{ Trial I } & \multicolumn{2}{c}{ Trial II } \\
\cline { 2 - 5 } & Count average & Category & Count average & Category \\
\hline Magnitude & 3.1 & positive & 3.2 & positive \\
\hline Generality & 2.9 & negative & 3.0 & positive \\
\hline Strength & 3.2 & positive & 3.3 & positive \\
\hline Overall Average & 3.07 & positive & 3.16 & positive \\
\hline
\end{tabular}

\section{Student Response}

Based on the analysis of the results of student responses, it was found that in the first and second trials, students were interested in the learning media developed. More clearly, the data is shown in Table 6 below:

Table 7.

Summary of Student Response Questionnaire Analysis Results

\begin{tabular}{ccccc}
\hline \multirow{2}{*}{ Respondent } & \multicolumn{2}{c}{ Trial I } & \multicolumn{2}{c}{ Trial II } \\
\cline { 2 - 5 } & $\%$ Average Score & Category & \% Average Score & Category \\
\hline Student & $90.2 \%$ & Interested & $91.5 \%$ & Interested \\
\hline
\end{tabular}

This can be seen from the average score of student responses showing interest in learning with the developed learning media. Judging from the percentage of student response questionnaire scores in the first trial of $90.2 \%$ with the interested category and in the second trial of $91.5 \%$ with the interested category. So it can be concluded that from the students' responses to the learning media assisted by macromedia flash that was developed effectively.

\section{Improving Student Self-Efficacy}

Research subjects consisting of 20 students were given a questionnaire with a total of 30 statement items consisting of 19 positive statements and 11 negative statements. Statements 1 to 10 are statements of the magnitude dimension related to the level (level) of task difficulty faced by students. Statements 11, 12, 13, 15, 17 14, 19, 18, 21 regarding the generality dimension which is a feeling of ability shown by students in different task contexts. The rest, namely statements 22, 23,24, 25, 28, 29,30, 26, 27 include the strength dimension which is the strength of students' beliefs regarding their abilities. The Likert scale questionnaire that was compiled presented four choices, namely SS (strongly agree), S (agree), TS (disagree) and STS (strongly disagree). Choice N (neutral) is not used to lead students to take sides. Each choice has a different score. In positive statements $\mathrm{SS}=5, \mathrm{~S}=4, \mathrm{TS}=2$ and $\mathrm{STS}=1$. On the contrary for negative statements $\mathrm{SS}=1, \mathrm{~S}=2, \mathrm{TS}=3$ and $\mathrm{STS}=4$.

After the questionnaire is distributed, the next step is to calculate the average of the whole and also of each 
dimension of self-efficacy. Based on the results of the distribution of the questionnaire, it was calculated that the overall average was 3.07 more than the neutral score which was the median of a scale of 5 so that in the first trial it was concluded that students' self-efficacy in learning was positive. Calculations are also carried out on each dimension to find out the average. Based on the table, information is obtained that the magnitude dimension of the arithmetic mean is 3.1 , which means it is positive. In the generality dimension, the arithmetic mean is 2.9 , which means it is negative because it is less than 3. Finally, for the strength dimension, the average is 3.2 , which means it is positive.

In the second trial, it was concluded that students' self-efficacy at a score of 3.16 in learning was in the positive category. Calculations are also carried out on each dimension to find out the average. Based on the table, information is obtained that the magnitude dimension of the arithmetic mean is 3.2 , which means it is positive. In the generality dimension, the arithmetic mean is 3.3, which means it is positive. Finally, for the strength dimension, an average of 3.16 is obtained, which means it is positive.

\section{Improving Students' Computational Thinking Ability}

Based on the results of the analysis of students' computational thinking ability tests in the first and second trials, it showed that there was an increase. The scores for increasing students' computational thinking skills in the first and second trials can be seen in table 7 below:

Table 8.

Improving Students' Computational Thinking Ability

\begin{tabular}{|c|c|c|}
\hline Students' Ce & tational & lking Abi \\
\hline & Trial I & Trial II \\
\hline Score & 0.3 & 0.4 \\
\hline Category & Low & Currently \\
\hline
\end{tabular}

Based on the average normalized gain, it was found that in the first trial there was an increase in the computational thinking ability of students with low criteria with a score of 0.3 (N-Gain ) and in the second trial there was an increase in scores with moderate criteria with a score of $0.4(0,3<\mathrm{N}$-Gain So it can be concluded that the developed learning media assisted by macromedia flash can improve students' computational thinking skills. $\leq 0,3 \leq 0,7)$.

Based on the validation results of the developed macromedia flash-assisted learning media, it was found that this learning media was valid or had a good degree of validity. Furthermore, the results of the validation of the lesson plans (RPP), student worksheets (LKPD), self-efficacy questionnaires of students' pretest and posttest students' computational thinking abilities were also valid. This means that the learning media and its devices can meet the demands of learning needs to improve students' computational thinking skills on the material of a threevariable linear equation system. Based on the results of the validation carried out by learning media experts, a score of 3.72 was obtained with the "Valid" category for the developed macromedia flash-assisted learning media. So that the learning media assisted by macromedia flash that was developed fulfills the demands of learning needs for the subject matter of a three-variable linear equation system. This is supported by the opinion of Rozak, Darmadi, and Murtafi'ah (2018: 40) that the learning media meets the validity criteria if it is said to be valid by the validator . In addition, Arsyad (2017: 75) says that one of the criteria for media that is worth choosing is media that is aligned and in accordance with the needs of the learning task. This opinion is also supported by Sutikno (2013: 112) who says that media is appropriate to use if it supports the content of learning materials. So it can be concluded that the learning media assisted by macromedia flash that has been developed has met the indicators of validity. This is supported by the opinion of Rozak, Darmadi, and Murtafi'ah (2018: 40) that learning media meet the validity criteria if they are said to be valid by the validator. In addition, Arsyad (2017: 75) says that one of the criteria for media that is worth choosing is media that is aligned and in accordance with the needs of the learning task. This opinion is also supported by Sutikno (2013: 112) who says that media is appropriate to use if it supports the content of learning materials. So it can be concluded that the learning media assisted by macromedia flash that has been developed has met the indicators of validity. This is supported by the opinion of Rozak, Darmadi, and Murtafi'ah (2018: 40) that learning media meet the validity criteria if they are said to be valid by the validator. In addition, Arsyad (2017: 75) says that one of the criteria for media that is worth choosing is media that is aligned and in accordance with the needs of the learning task. This opinion is also supported by Sutikno (2013: 112) who says that media is appropriate to use if it supports the content of learning materials. So it can be concluded that the learning media assisted by macromedia flash that has been developed has met the indicators of validity. 75) who said that one of the criteria for media that deserves to be selected is media that is aligned and in accordance with the needs of the learning task. This opinion is also supported by Sutikno (2013: 112) who says that media is appropriate to use if it supports the content of learning materials. So it can be concluded that the learning media assisted by macromedia flash that has been developed has met the indicators of validity. 75) who said that one of the criteria for media that was worth choosing was media that was aligned and in accordance with the needs of the learning task. This opinion is also supported by Sutikno (2013: 112) who says that media is appropriate to use if it supports the content of learning materials. So it can be concluded that the learning media assisted by macromedia 
flash that has been developed has met the indicators of validity.

The results of the assessment of the experts (validators), all validators stated that the learning mediahelp macromedia flash developed is feasible to use with a few revisions. This is supported by the opinion of Akker (2007: 66) which states that the criteria for the practicality of learning media are said to be practical if the validator assesses that what is developed can be applied. This is in line with the research of Annisa, Putra, and Dharmono (2020: 78) which states that the practicality of learning media is important to know because one of the requirements for learning media is that it is easy to use by users.

Hasratuddin (2018: 242) states that the indicators of learning effectiveness are based on the achievement of mastery learning if $>80 \%$ of students have completed, the time used in learning is efficient or does not exceed ordinary learning, and student responses to positive learning. Based on the results of trial I and trial II, the developed learning media has met the effective category in terms of the achievement of students' computational thinking abilities, active student activities, and positive responses from students. As forThe posttest achievement of students' computational thinking abilities in the first trial was the same, which was $55.2 \%$ with 11 students declared complete. So, it can be concluded that in the first trial the application of learning mediahelp macromedia flash that developed did not meet the criteria for achieving classical completeness $(>80 \%)$. However, in the second trial, the posttest achievement of students' reasoning abilities and understanding of mathematical concepts had met the specified criteria, which was $867 \%$ with 17 students declared complete. So, it can be said that the learning mediahelp macromedia flash has met the criteria of effectiveness in the aspect of the achievement of students' computational thinking abilities.

Based on the analysis of the results of observing student activities in the first trial, the average percentage of achieving the ideal time of student activity for two meetings in the first trial was obtained is $21.8 \%, 18.4 \%, 20.9 \%$, $26.0 \%, 10.7 \%$ and $3.0 \%$. Meanwhile, in the second trial, the average percentage of students' achievement in the ideal time for three meetings was $21.8 \%, 19.2 \%, 21.0 \%, 26.0 \%, 9.8 \%$ and $1.8 \%$. Based on these data, it can be concluded that all student activities in the second trial also meet the ideal percentage of time set.

The results of the analysis of student self-efficacy observations showed that students' self-efficacy in learning mathematics using macromedia flash-assisted learning media was in the positive category. Calculations are also carried out on each dimension to find out the average. Based on the table, it was obtained information that at the end of the second trial, the magnitude dimension of the arithmetic mean was 3.2, which means positive. In the generality dimension, the arithmetic mean is 3.3 , which means it is positive. Finally, for the strength dimension, an average of 3.16 is obtained, which means it is positive.

The results of the analysis of the results of student responses that have been described previously, it was found that in the first trial and second trial, students were interested in the learning media developed. This can be seen from the average score of student responses showing interest in learning with the developed learning media. Judging from the average score of the student response questionnaire in the first trial of 90.2 with the attractive category and in the second trial it was $91.5 \%$ with the interested category. So it can be concluded that from student responses to learning mediahelp macromedia flash effectively developed. According to Arsyad (2017: 25) learning using learning media is considered to attract attention and keep students awake and paying attention. In other words, learning media is able to make teaching and learning activities in the classroom effective.From the description of all aspects of the effectiveness of learning media above, it can be concluded that the learning media assisted by macromedia flash that was developed is effective for use in learning comparative materials to improve students' computational thinking skills.

Based on the results of the analysis of students' computational thinking ability tests in the first and second trials, it showed that there was an increase. Based on the average normalized gain, it was found that in the first trial there was an increase in students' reasoning abilities with the "low" criteria with a score of 0.3 (N-Gain) and in the second trial there was an increase in the value with the "medium" criteria with a score of $0,4(0.3<\mathrm{N}$-Gain . So it can be concluded that the learning media assisted by macromedia flash with the application of this developed Problem Based Learning learning model can improve students' computational thinking skills. $\leq 0,3 \leq 0,7$ )

\section{CONCLUSION}

Based on the research conducted, it can be concluded that: 1) in terms of the analysis of the results of the validity of the learning media by the validators with a total average value of 3.72;2) Macromedia flash-assisted learning media that was developed met the criteria for the practicality of learning media in terms of the analysis of the results of observing the implementation of learning. The score obtained in the first trial was 2.75 (category "Poorly Implemented") and did not meet the criteria for research success. However, after making several revisions, in the second trial the learning implementation observation score increased to 3.73 (category "Well Implemented"). So that the learning media developed successfully meets the criteria for the practicality of learning media; 3 ) the developed learning media has met the established effectiveness criteria. In the first trial the achievement of students' computational thinking skills was $55.2 \%$ (11 students) and in the second trial it was $87 \%$ (17 students). The average percentage of students' ideal time of achievement for the four meetings in the first trial was $21.8 \%$, 
$18.4 \%, 20.9 \%, 26.0 \%, 10.7 \%$ and $3.0 \%$. While in the second trial, the average percentage of students' ideal time for three meetings was $21.8 \%, 19.2 \%, 21.0 \%, 26.0 \%, 9.8 \%$ and $1.8 \%$. At the end of the second trial, the student's self-efficacy score was 3.16, this shows that the student's self-efficacy is in the positive category, the average magnitude dimension is 3.2, which means it is positive. In the generality dimension, the arithmetic mean is 3.3 , which means it is positive. Finally, for the strength dimension, an average of 3.16 is obtained, which means it is positive. The average student response in the first trial was $90.2 \%$ and in the second trial was $91.5 \%$; 4) the improvement of students' computational thinking ability is also seen in each indicator of their ability. Based on the normalized gain index, it was found that in the first trial there was an increase in the value with a low criterion score of 0.3 (N-Gain) and in the second trial there was an increase in the value with a moderate criterion with a score of $0.40(0.3<\mathrm{N}$-Gain So it can be concluded that the developed learning media assisted by macromedia flash can improve students' computational thinking ability. 4) the improvement of students' computational thinking ability is also seen in each indicator of their ability. Based on the normalized gain index, it was found that in the first trial there was an increase in the value with a low criterion score of 0.3 (N-Gain) and in the second trial there was an increase in the value with a moderate criterion with a score of $0.40(0.3<\mathrm{N}$-Gain So it can be concluded that the developed learning media assisted by macromedia flash can improve students' computational thinking ability. 4) the improvement of students' computational thinking ability is also seen in each indicator of their ability. Based on the normalized gain index, it was found that in the first trial there was an increase in the value with a low criterion score of 0.3 (N-Gain) and in the second trial there was an increase in the value with a moderate criterion with a score of $0.40(0.3<\mathrm{N}$-Gain So it can be concluded that the developed learning media assisted by macromedia flash can improve students' computational thinking ability. $\leq 0,3 \leq 0,7$ )

\section{BIBLIOGRAPHY}

Arsyad, A. 2015.Media Pembelajaran. Jakarta: RajaGrafindo Persada

Astuti, D. 2006. Macromedia Flash 8. Yogyakarta: Penerbit Andi

Hake, R.R (1999). Analyzing Change/Gain Scores. Woodland Hills : Dept. of Physics, Indiana University.

Hasratuddin., (2015), Mengapa Harus Belajar Matematika?, Perdana Publishing,Medan. -444

Kemendikbud., (2016), Peraturan Menteri Pendidikan dan Kebudayaan Republik Indonesia Nomor 21 Tahun 2016 Tentang Standar Isi Pendidikan Dasar Dan Menengah,Kemendikbud, Jakarta.

Rusman. (2013a), Belajar dan Pembelajaran Berbasis Komputer Mengembangkan Profesionalisme Guru Abad 21, Bandung: Alfabeta.

Rusman. (2013b), Seri Manajemen Sekolah Bermutu Model-Model Pembelajaran Mengembangkan Profesionalisme Guru, Jakarta: Raja Grafindo Persada. 